\title{
Clinical significance of the molecular heterogeneity of gastrointestinal stromal tumors and related research: A systematic review
}

\author{
HAIXIANG DING ${ }^{1,2}$, XIUCHONG YU $^{1,2}$, YU YU $^{1}$, XIFENG LAO $^{1}$, CHEN HANG $^{1}$, \\ KAIJUN GAO $^{1}$, YANGTAO JIA ${ }^{1}$ and ZHILONG YAN ${ }^{2}$ \\ ${ }^{1}$ Medical School of Ningbo University, Department of Biochemistry and Molecular Biology, \\ Zhejiang Key Laboratory of Pathophysiology, Ningbo, Zhejiang 315211; \\ ${ }^{2}$ Department of Gastrointestinal Surgery, The Ningbo First Hospital and The Affiliated Hospital \\ of The Medical School of Ningbo University, Ningbo, Zhejiang 315010, P.R. China
}

Received September 2, 2019; Accepted December 19, 2019

DOI: $10.3892 /$ or. 2020.7470

\begin{abstract}
Gastrointestinal stromal tumors (GISTs) are the most commonly observed mesenchymal tumors of the digestive tract, and they originate from the interstitial cells of Cajal. GISTs can be divided into KIT/PDGFRA-mutant GISTs and wild-type GISTs based on the presence or absence of KIT/PDGFRA mutations. Wild-type GISTs can be divided into succinate dehydrogenase complex (SDH)-deficient GISTs and non-SDH-deficient GISTs. Downstream signaling pathways activated by these mutations serve a pivotal role in the
\end{abstract}

Correspondence to: Professor Zhilong Yan, Department of Gastrointestinal Surgery, The Ningbo First Hospital and The Affiliated Hospital of The Medical School of Ningbo University, 59 Liuting Street, Ningbo, Zhejiang 315010, P.R. China

E-mail: yanzhilong@nbu.edu.cn

Abbreviations: GISTs, gastrointestinal stromal tumors; KIT, a receptor tyrosine kinase; PDGFRA, platelet derived growth factor receptor $\alpha$; JAK2, Janus kinase 2; STAT3, signal transducer and activator of transcription 3; GDP, guanosine diphosphate; GTP, guanosine triphosphate; RAF, RAF proto-oncogene serine/threonine-protein kinase; MEK, mitogen-activated protein kinase kinase; MAPK, mitogen-activated protein kinase; PI3K, phosphoinositide 3-kinase; AKT, protein kinase B; mTOR, mammalian target of rapamycin; PIP3, phosphatidylinositol-3,4,5-triphosphate; PIP2, phosphatidylinositol-4,5-bisphosphate; PTEN, phosphatase and tensin homolog; BAD, BCL2 associated agonist of cell death; $\mathrm{SDH}$, succinate dehydrogenase; HIF1, hypoxia-inducible factor; IGF, insulin-like growth factor; VEGF, vascular endothelial growth factor; JM, juxtamembrane; EC, extracellular domain; TKI, TKI domain (ATP-binding pocket); TKII, TKII domain (activation loop); NF1, Neurofibromatosis type 1; GI, Gastrointestinal; cfDNA, cell free DNA; ctDNA, circulating DNA

Key words: gastrointestinal stromal tumors, KIT, PDGFRA, RAS, SDH, neurofibromin 1, signal transducers and activators of ttranscription 3, non-coding RNAs, ctDNA development of GISTs and are associated with the biological behavior, including risk stratification, clinical prognosis and drug resistance. Accurate medical care requires accurate molecular diagnosis, which in turn prolongs the survival of patients with GISTs and makes GIST a chronic disease. At present, there is a lack of effective treatment for imatinib/sunitinib/regorafenib resistant patients and KIT/PDGFRA-WT GISTs, which is undoubtedly a major challenge for future research. The present review summarizes the molecular pathogenesis of GISTs and the progress of related research.

\section{Contents}

1. Introduction

2. KIT mutations

3. PDGFRA mutations

4. Familial GISTs

5. Wild-type GISTs

6. ctDNA and GISTs

7. Non-coding RNAs and GISTs

8. Conclusion

\section{Introduction}

Gastrointestinal stromal tumors (GISTs) are found in the stomach $(56 \%)$, small intestine $(32 \%)$, colon and rectum $(6 \%)$, esophagus $(0.7 \%)$, and other areas, such as the omentum, intestinal membrane, pelvis and retroperitoneum (5.5\%) (1). The symptoms of GISTs are often non-specific, and dependent on the size and location of the mass. Many small GISTs $(<2 \mathrm{~cm})$ are frequently found by endoscopy or radiographic examination, and these patients typically have no symptoms. The most common symptom observed is gastrointestinal bleeding, which is observed in $~ 50 \%$ of patients, followed by abdominal pain (20-50\% of patients) and gastrointestinal obstruction (10-30\% of patients). Other symptoms include melena, hematemesis, feeling satiated and a palpable abdominal mass. 
Proximal gastric stromal tumors may cause difficulty in swallowing, while tumors located in the pylorus may present as a gastric outlet obstruction $(2,3)$. At initial diagnosis, $\sim 20 \%$ of patients present with metastases (4), which typically occur in the abdominal cavity or liver, whereas lung, bone or brain metastases are rare. Lymph node metastasis occurs in $20-60 \%$ of children with GISTs and Carney's triad, whereas other types are rare $(<10 \%)(5,6)$. In addition, GIST-induced expendable hypothyroidism and IGF-II production-related non-islet cell tumor hypoglycemia have also been reported. Therefore, patients with endocrine and metabolic symptoms should also be included in differential diagnosis $(7,8)$.

There are numerous molecular subtypes of GISTs (Fig. 1). In $\sim 85-90 \%$ of patients with GISTs, KIT (KIT proto-oncogene, receptor tyrosine kinase) or PDGFRA (platelet derived growth factor receptor $\alpha$ ) gene mutations are present which alter cell proliferation, adhesion, apoptosis, survival and differentiation by regulating downstream signaling pathways, including the RAS/RAF/mitogen-activated protein kinase (MAPK) and PI3K/AKT/mTOR signaling pathways (Fig. 3A and B) (9). The remaining $10-15 \%$ of GISTs, which do not possess KIT or PDGFRA gene mutations, are referred to as wild-type GISTs (10).

Studies have shown that non-coding RNAs [long non-coding RNAs (lncRNA) and microRNAs (miRNAs)] are associated with the invasion, proliferation and drug resistance of GIST cells $(11,12)$. Detection of circulating (ct)DNA may also contribute to the early diagnosis of GISTs (13).

The global incidence of GISTs (1-1.5 cases/100,000 individuals) and the prevalence rate ( 13 cases $/ 100,000$ individuals) are low (14). Incidence rates in Shanghai, Hong Kong and Norway are relatively higher (1.9-2.1 cases/100,000 individuals), whereas the incidence in the Shanxi Province is relatively lower (4.3 cases/1,000,000 individuals). The median age of diagnosis is 60 years (range, 10-100), but may be diagnosed at any age; $\sim 50 \%$ of cases are identified in individuals aged $30-59$, there is no significant difference in occurrence between males and females, and the incidence in individuals $<20$ years is rare $(<0.5 \%$ of all cases) $(15,16)$.

\section{KIT mutation}

There are two types of KIT receptors; the wild-type (145 kDa) and the mutant-type (125 kDa) receptor (17). The human KIT gene is a proto-oncogene located on chromosome 4q12-13. Its products belong to the receptor tyrosine kinase class III family, which also includes PDGFRA, PDGFRB, CSF1R and FLT3 receptor (18). The receptor tyrosine kinase class III family is characterized by an extracellular ligand binding domain, which consists of five immunoglobulin-like regions. In addition, the kinase structure includes a transmembrane domain, a juxtamembrane membrane domain and an intracellular kinase domain (Fig. 2). KIT is associated with many human malignancies, including small cell lung cancer, malignant melanoma, colorectal cancer and GISTs. More than 500 different KIT mutations have been discovered in human tumors but only a few of these are considered driver mutations (19). As a KIT ligand, stem cell factor (SCF) can induce receptor dimerization and activation of intrinsic tyrosine kinase activity after binding to the receptor, thus creating docking sites for signaling molecules containing SRC homologous domain 2 (SH2). The $\mathrm{SH} 2$ domain is present in numerous signal transduction molecules and consists of $\sim 100$ amino acids. It can regulate cell growth by binding phosphorylated tyrosine residues, including Tyr 568, Tyr 570, Tyr 703, Tyr 721, Tyr 730, Tyr 823, Tyr 900 and Tyr 936. Phosphorylated tyrosine, together with adjacent amino acid residues, forms a specific binding site for downstream signaling molecules and activates specific downstream signaling pathways, including the MAPK and PI3K/AKT pathways. The former results in the upregulation of transcription factors, such as MYC, ELK, CREB and FOS, whereas the latter results in the downregulation of cell cycle inhibitors and the enhancement of anti-apoptotic effects (20). Phosphorylation of Tyr 568 serves an important role in the activation of KIT and downstream signaling pathways. Phosphorylated Tyr 568 activates the SRC family kinase and in turn promotes activation of the KIT gene (21). SRC activity in tumors of patients with GISTs is significantly higher compared with that noted in normal tissues (22). Inhibition of SRC family kinase activity weakens KIT activation, suggesting that the activity of the SRC family kinase is necessary for the complete activation of KIT. In addition, SRC family kinases activate SHC to activate the downstream RAS/RAF/MEK/MAPK signaling pathway, which is involved in KIT-mediated cell proliferation (21). Another important KIT phosphorylation site is Tyr 721, which serves as a docking site for the regulatory subunit $\mathrm{p} 85$ of PI3K (23). Tyr 703 and Tyr 936 serve as binding sites of Grb2 which are recruited to activate the downstream PI3K/AKT and RAS/RAF/MEK/MAPK signaling pathways (24).

The signal transducers and activators of transcription (STAT) family of proteins is also associated with KIT signaling (25). Binding of SCF to the KIT receptor results in binding of JAK2 to c-kit, followed by autophosphorylation leading to phosphorylation of STAT1, STAT3 and STAT5. Phosphorylated STAT subsequently translocates to the nucleus where it binds to the promoter region of target genes to regulate transcription (26). At present, it is hypothesized that cell cycle disorders caused by genomic inactivation of cell cycle regulatory genes are a common mechanism during the transition from low-risk to high-risk metastatic GISTs (27).

The majority of GISTs (70-80\%) have KIT gene mutations, which result in activation of c-Kit without SCF binding, thus increasing the activity of downstream signaling pathways (28). Mutations have been identified in exon 11 (70-80\%) which encodes the juxtamembrane domain; exon 9, (10\%) which encodes the extracellular domain; exon 13, which encodes the TK I domain (1\%); and exon 17 (1\%), which encodes the TK II domain (29,30). Mutations in the juxtamembrane domain affects the regulatory function of itself and increases auto-activation of the kinase. Mutations in the extracellular domain may disrupt the anti-dimerization motif and lead to homodimerization of the receptor (31).

Mutations in exon 11 are concentrated in the hot spots of codon 550-560 at the $5^{\prime}$ end. The most frequently observed type of mutation is deletion at codon 557-558 at the 5' end, followed by deletion mutations at codon 559 and point mutations resulting in V575A (32). Imatinib has desirable therapeutic effects in the majority of patients with GISTs with mutations of the KIT gene. However, exon 11 mutations involving codon 557-558 deletion have also been demonstrated 


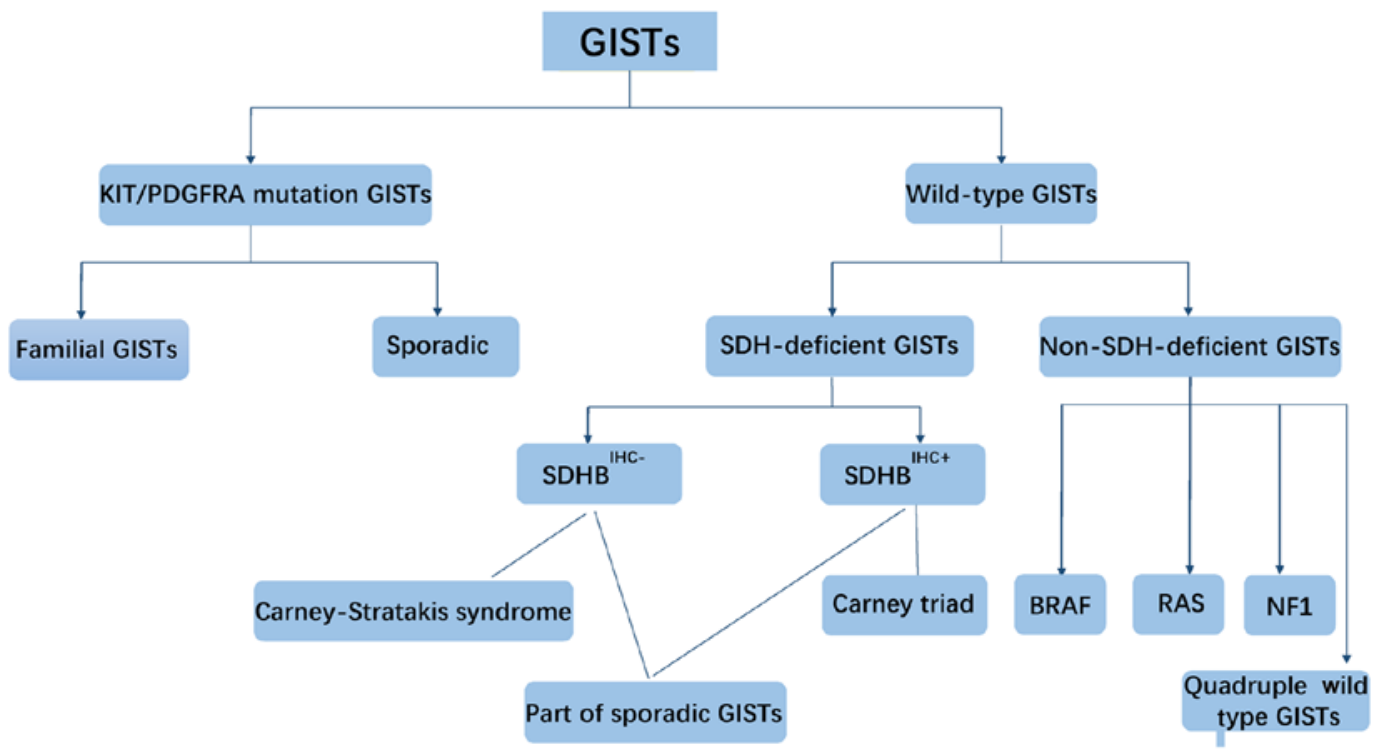

Figure 1. Classification of GISTs. GISTs, gastrointestinal stromal tumors; KIT, KIT, KIT proto-oncogene, receptor tyrosine kinase; PDGFRA, platelet derived growth factor receptor $\alpha$; SDH, succinate dehydrogenase BRAF, B-Raf proto-oncogene, serine/threonine kinase; NF1, neurofibromin 1.

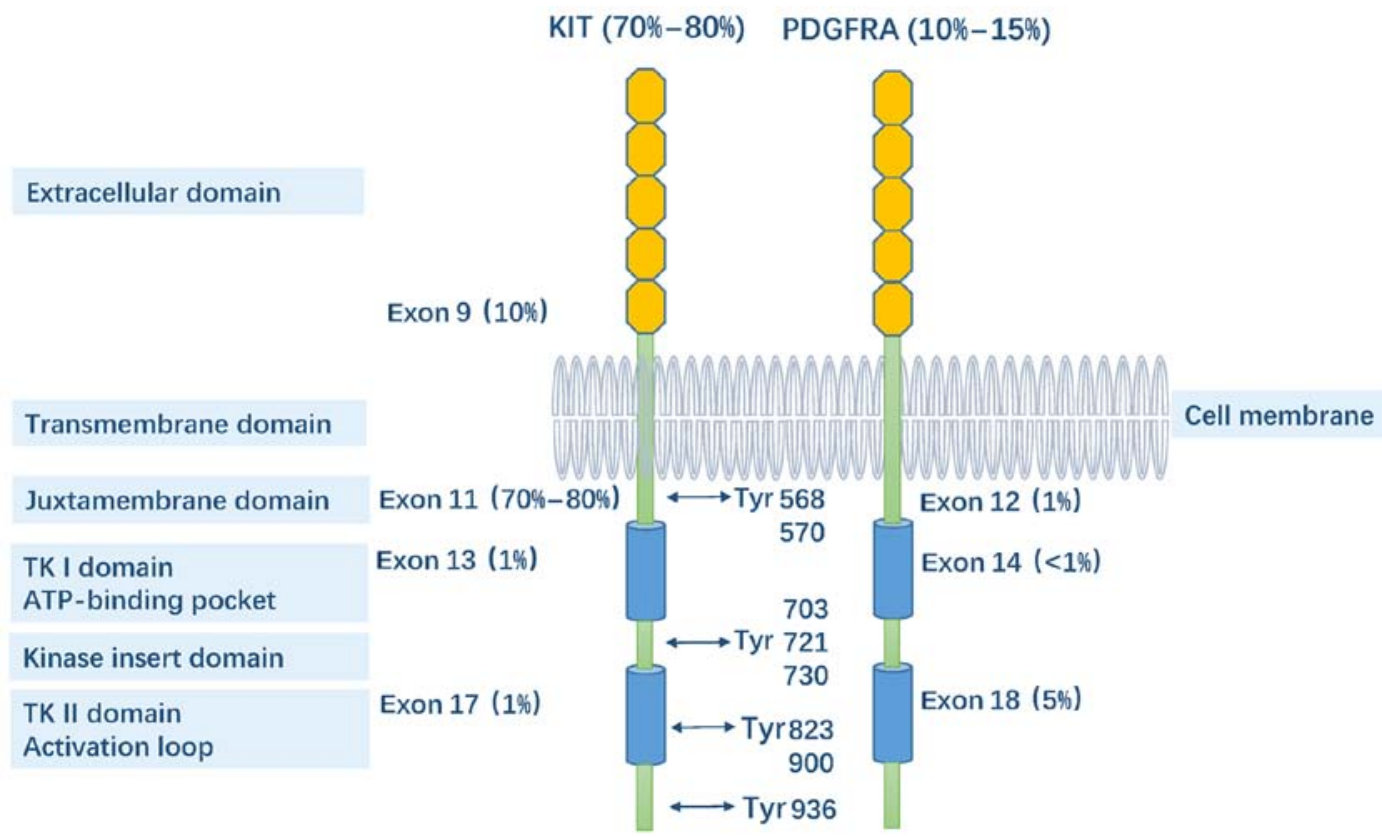

Figure 2. Structure of KIT and PDGFRA receptors. The main mutation sites and phosphorylation sites of KIT and PDGFRA in sporadic GISTs. GISTs, gastrointestinal stromal tumors; KIT, KIT, KIT proto-oncogene, receptor tyrosine kinase; PDGFRA, platelet derived growth factor receptor $\alpha$.

to increase the malignant potential of a tumor and reduce recurrence-free survival (RFS) (33-35). A European multicenter analysis showed that deletion mutations in exon 11 of the KIT gene at codon 557-558 may be used as a reference factor predicting a less favorable prognosis (36). In another retrospective study, moderate-risk patients with KIT exon 11 deletion mutations had similar recurrence-free survival (RFS) to those with high-risk diseases, whereas those with no KIT exon 11 deletion mutation exhibited similar clinical manifestations to those of very low-risk and low-risk patients. These findings also help to assess the prognosis of patients at moderate risk with deletion mutations in exon 11 deletion (37). Patients with KIT exon 11 mutations exhibit improved drug responses and higher overall survival compared with patients with KIT exon 9 mutations and those lacking KIT or PDGFRA mutations (31). This was also verified in phase I and phase II trials in Europe (38).

Patients with exon 9 mutations, characterized by codon 502-503 duplication had a higher recurrence and metastasis rate, were significantly associated with larger tumor morphology, tumor growth site (located in the small intestine) and spindle cell type tumor cells (39). There is also a relatively higher incidence of exon 9 mutations in men (40). In a Japanese population-based study, 4 patients with exon 9 mutations were also found to be at high risk and all died of metastasis. These results also suggest that mutation in exon 9 is associated with 


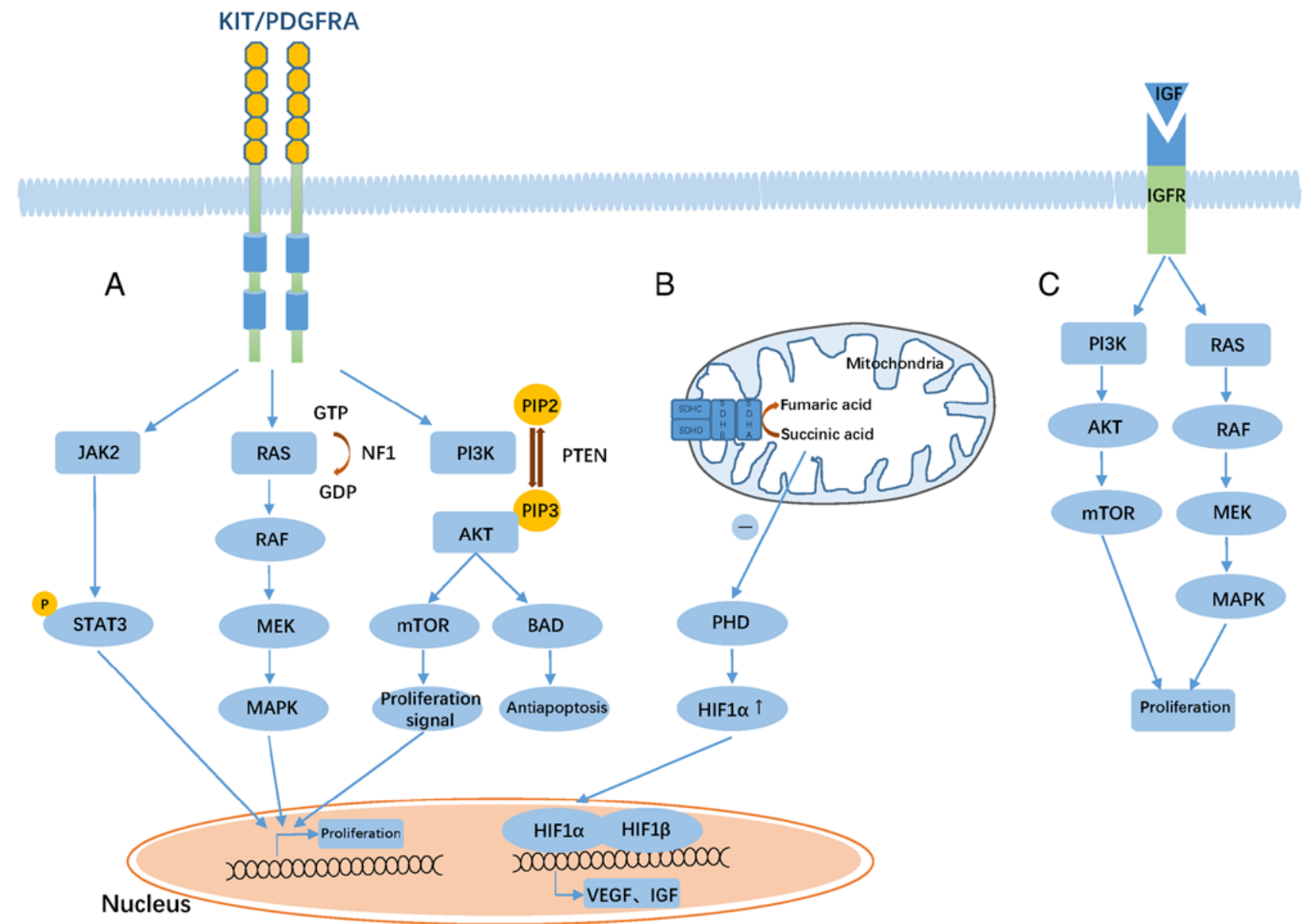

Figure 3. Key signaling pathways in GISTs. (A) KIT or PDGFRA oncogenic mutations in GISTs initiate a related signaling pathway leading to activation of STAT, MAPK and PI3K signaling pathways. The NF1 protein regulates the RAS signaling pathway by catalytically activating GTP hydrolysis to inactive GDP. The PTEN tumor-suppressor gene terminates the signaling pathway by dephosphorylation of inositol PIP3 into PIP2. (B and C) SDH deficiency causes the accumulation of succinic acid which inhibits the activity of PHD caused by the accumulation of hypoxia-inducible factor $\alpha$ (HIF1 $\alpha)$. HIF1 $\alpha$ enters the nucleus and binds to HIF1 $\beta$ to induce overexpression of glycolytic and angiogenic genes (including IGF and VEGF), which in turn acts on the RAS/RAF/MAPK and PI3K/AKT signaling pathways promoting the development of GISTs. GISTs, gastrointestinal stromal tumors; KIT, KIT, KIT proto-oncogene, a receptor tyrosine kinase; PDGFRA, platelet derived growth factor receptor $\alpha$; JAK2, Janus kinase 2; STAT3, signal transducer and activator of ttranscription 3; GDP, guanosine diphosphate; GTP, guanosine triphosphate; RAF, RAF proto-oncogene serine/threonine-protein kinase; MEK, mitogen-activated protein kinase kinase; MAPK, mitogen-activated protein kinase; PI3K, phosphoinositide 3-kinase; AKT, protein kinase B; mTOR, mammalian target of rapamycin; PIP3, phosphatidylinositol-3,4,5-triphosphate; PIP2, phosphatidylinositol-4,5-bisphosphate; PTEN, phosphatase and tensin homolog; BAD, BCL2 associated agonist of cell death; SDH, succinate dehydrogenase; HIF1, hypoxia-inducible factor; IGF, insulin-like growth factor; VEGF, vascular endothelial growth factor.

a less favorable prognosis. However, $75 \%$ of Japanese patients with exon 9 mutations possessed a GIST located in the stomach, and the conclusion that this mutation type is more common in the small intestine suggested by Losata et al (41) was not observed, which may be related to different ethnicities (42). Controversially, no other studies have found any association between exon 9 mutations and a poor prognosis (43). Mutation screening for exon 9 is considered to have guiding significance for GIST treatment since these claim a higher dose of imatinib to be effective, and thus also is of great significance for the treatment. Besides after progression to imatinib resistance, GISTs with KIT mutations at exon 9 and wild-type GISTs seem to respond better to sunitinib (44).

Typically, primary mutations occur in exons 9 and 11, whereas secondary mutations most frequently occur in exon 13 encoding the TK I domain and exon 17 encoding the TK II domain. Most cases of metastatic secondary mutated GISTs have multiple mutations at the same time, both between different metastases and within the same metastatic deposit.
Of the secondary mutations in KIT, $\sim 30-40 \%$ are secondary KIT exon 17 mutations, accounting for resistance to imatinib or sunitinib in patients with GIST $(45,46)$. In these patients, regorafenib shows therapeutic efficacy (47). Conversely, patients with secondary exon 13 mutations typically respond to sunitinib but not regorafenib (48).

The majority of mutations in exon 13 of KIT in GISTs are K642E mutations caused by base substitution (c.1945A $>$ G; c.1948G $>$ A) (49). These base substitution mutations result in constitutive activation of tyrosine phosphorylation, independent of ligand binding, which activates specific downstream signaling transduction pathways and promotes cell proliferation (50). The majority of mutations in exon 17 of KIT in GISTs are N822K (70\%), which also result in maintenance of tyrosine phosphorylation activity (50). Less frequently observed mutations (N822Y, N822K, N822H, D816F, D816Y, D820Y, D820V, D816V and Y823D) have been identified in exon $17(40,49)$. D816V has also been found in several other human malignant tumors, including acute myeloid 
leukemia (51), mastocytosis (52), germ cell tumors (53), sinus natural killer/T cell lymphoma (54) and intracranial teratoma (55), but is relatively rare in GISTs. Mutations at codon 816 result in constitutive activation of the receptor, which activates the downstream PI3K/AKT signaling pathway. Most KIT exon 13 or exon 17 mutants have spindle-cell morphology, and fewer tumors have epithelioid cell characteristics. Gastric tumors with KIT exon 13 mutations are associated with increased invasiveness, whereas small intestine tumors with KIT exon 13 and exon 17 mutations did not result in any significant differences in behaviors compared with other mutant small intestine GISTs (49).

Furthermore, deletion mutations in chromosomes $14 \mathrm{q}$ and $22 q$ are considered early events in the progression of KIT/PDGFRA mutant GISTs. Inactivation of dystrophin is hypothesized to be a late event in the progression of GISTs. Dystrophin is a tumor suppressor which is inactivated in $96 \%$ of metastatic GISTs but not in low-risk GISTs (27).

\section{PDGFRA mutations}

KIT mutations and PDGFRA mutations are mutually exclusive in GISTs. However, GISTs expressing KIT or PDGFRA oncoprotein exhibit similar mechanisms of tumorigenesis and progression (56). PDGFRA mutations exist in 10-15\% of GISTs and are found in exon 12 which encodes the membrane proximal domain (1\%), exon 14 which encodes the TK I domain (N659Y, N659K; <1\%) and exon 18 which encodes the TK II domain (D824V, D842Y; 5\%, I843_del, I843-H845_del, I843_del, I843-H845_del, D842-H845_del, D842-M844_del, D842-H845_del, D842-M844_del; 1\%). Secondary mutations associated with secondary resistance occur primarily in exons 14 and 18. The majority of the PDGFRA mutations affect the TK II domain. These mutations alter the activation loop, modulating the ATP binding pocket and causing kinase activation leading to downstream signal transduction pathways that promote cell survival and proliferation $(56,57)$. Protein kinase B (Akt), MAPK, and STAT1 and STAT3 in PDGFRA-mutant GISTs are uniformly activated, resulting in the activation of the same signaling pathways as KIT-mutant GISTs. PDGFRA-mutant GISTs are primarily epithelioid and are predominantly present in the stomach (58). Expression of CD117 in these tumors is weak or absent $(56,59)$. PDGFRA-mutant GISTs are less invasive, accounting for only $2.1 \%$ of metastases in patients with GISTs $(4,60)$.

The most common mutation type of PDGFRA in GISTs is $\mathrm{D} 842 \mathrm{~V}$ mutation in exon 18 (accounting for $9.8 \%$ of all mutations and $65 \%$ of exon 18 mutations in PDGFRA). The substitution of a valine at codon 842 by aspartic acid leads to resistance to first- and second-line tyrosine kinase inhibitors (TKIs) such as imatinib and sunitinib in patients, and therefore, these patients do not benefit from treatment with TKIs (61). It is also worth noting that in gastric tumors with a PDGFRA mutation, the vast majority of the advanced cases carry the exon 18 PDGFRA D842V mutation (36). Avapratinib (BLU-285) is a novel inhibitor that specifically targets KIT exon 17 and PDGFRA D842 mutations. The results of the phase I NAVIGATOR trial showed that the overall response rate (ORR) of patients with PDGFRA D842V mutation was $84 \%$ and treatment caused tumor shrinkage in $98 \%$ of cases.
The NAVIGATOR phase I trial included four different groups of patients with GISTs: i) GISTs treated with second-line therapeutics; ii) GISTs being treated with third- or fourth-line therapeutics that were regorafenib-naïve; iii) GISTs being treated with fourth-line or more advanced line therapeutics; and iv) PDGFRA D842V-mutated GISTs. In the second-line treatment group, the reported avapritinib ORR was $25 \%$. In patients being treated with third- or fourth-line therapeutics that were regorafenib-naïve, avapritinib was associated with an ORR of $26 \%$. In the patients being treated with fourth-line or more advanced line therapeutics, ORR was $20 \%$. In addition, in vitro studies have shown that crenolanib exhibited improved antiproliferative effects compared with imatinib for patients with this type of mutation. Phase III clinical trials of crenolanib (Randomized Trial of Crenolanib in Subjects with D842V Mutated GIST; clinicaltrials.gov identifier, NCT02847429), and phase III randomized trials of avapritinib and regorafenib (VOYAGER, NCT03465722) are also on-going (62). The majority of GISTs with PDGFRA mutations excluding D842V mutation still respond to imatinib, therefore mutation screening is of great significance for the treatment of GIST (63).

PDGFRA mutations are also found in exon 12 (juxtamembrane domain; JM) and exon 14 (TK I domain), but are relatively rare (64). Among these, exon 12 point mutation V561 A is the second most common type of PDGFRA mutation (65). The majority of the exon 14 mutations of PDGFRA are N659K point mutations. Clinical data showed that most tumors with this mutation were located in the stomach, and most of these were epithelioid cells with relatively good prognosis (66).

\section{Familial GISTs}

The majority of KIT and PDGFRA mutations are sporadic and are only found in GIST tissues. However, there are also patients with rare familial GISTs with autosomal dominant inheritance, and affected family members have a $100 \%$ penetrance rate (67). Clinical manifestations include dysphagia, excessive skin pigmentation, urticaria pigmentation and mastocytosis. These patients have the same type of germline KIT and PDGFRA mutations as the somatic mutant GISTs. KIT mutations in familial GIST patients have been found in exon 11 (V559A, W557R, D579 del) (68-70), exon 17 (D820Y) (71) and exon 8 (D419 del) (72). The PDGFRA mutation was also found in exon 18 (D846Y) (73). Histologically, familial GISTs are basically the same as that of patients with sporadic GISTs, but there are multiple lesions, primarily from the proliferation of interstitial cells of Cajal. Identification of patients with familial GISTs is important as the clinical management patterns are different from those of GISTs with somatic mutations. Nevertheless, currently there are no specific treatment options for such patients. Considering the presence of multiple lesions, conservative resection is often adopted in most medical institutions.

\section{Wild-type GISTs}

Most GISTs are driven by oncogenic KIT or PDGFRA receptor tyrosine kinase activating mutations. However, $10-15 \%$ of GISTs lack KIT and PDGFRA mutations, and are referred 
to as wild-type GISTs. Wild-type GISTs can be divided into succinate dehydrogenase complex (SDH)-deficient and non-SDH-deficient GISTs (63). Mutations of any of the four SDH subunits or of members of the RAS pathway [(K/N/H-RAS, BRAF, neurofibromatosis type 1 (NF1)] have been observed in wild-type GISTs.

Whole-genome sequencing revealed that the genome of wild-type GISTs exhibit a low mutation frequency, and only $\sim 25 \%$ of patients have chromosomal imbalances. Mutations in the 14q23.1 region of KIT/PDGFRA-mutant GISTs result in downregulation of tumor suppressor RTN1, DAAM1 and DACT1, but mutations in the same region in wild-type GISTs does not result in these effects (74). Wild-type GISTs tend to develop in younger patients; $~ 85 \%$ of GISTs in patients $<23$ years of age are wild-type. Lesions are primarily present in the stomach, and the volume of the tumor is often small, but lymph node metastases are more common. TKIs are often less effective in these cases (75-77).

SDH-deficient GISTs. Succinate dehydrogenase complex (SDH; also known as mitochondrial complex II) deficiency is more common in wild-type GISTs, accounting for $5 \%$ of all GISTs. The lack of SDH is considered to be an important feature of several human tumor subtypes, including GISTs, paraganglioma, renal cell carcinoma and pituitary adenomas (78). SDH is a complex of enzymes located on the mitochondrial inner membrane, and consists of four subunits (SDHA, SDHB, SDHC and SDHD) and two kinds of succinate dehydrogenase assembly factors (SDHAF1 and SDHAF2), which are components of the tricarboxylic acid cycle and the respiratory electron transport chain.

Approximately $50 \%$ of subunit mutations are found in SDH-deficient GISTs, and the most frequently observed being SDHA which are primarily germline mutations, accounting for $\sim 30 \%$ of all mutations, with mutations in other subunits accounting for the remaining $20 \%$ (79). SDHA-mutant GISTs can be individually identified by SDHA immunohistochemistry. In the other $50 \%$ of cases, no subunit mutation is observed, but immunohistochemistry showed a significant decrease or deletion of SDHB protein expression, and the respiratory chain complex II enzyme activity was lost as well. This may be due to epigenetic modifications or related protein defects involved in maintaining stability (80).

Defects in any of the subunits, particularly defects in SDHB, will result in instability of the SDH complex, which in turn affects the function of the complex. When the SDH complex is dysfunctional, there is an accumulation of succinic acid in the cytoplasm which results in the accumulation of hypoxia inducible factor 1 subunit $\alpha$ (HIF1 $\alpha$ ). HIF $1 \alpha$ transcriptionally upregulates hypoxia-related tumorigenic processes and angiogenesis. Thus, defects in energy metabolism are key carcinogenic mechanisms (81). Therefore, if any of the SDH subunits are mutated/inactivated, immunohistochemical staining of SDHB is absent, and as such SDHB-negative staining is now considered to be a highly sensitive marker for any SDH subunit germline mutation $(80,82)$.

SDH-deficient GISTs occur primarily in children and patients with Carney-Stratakis syndrome and Carney triad which affects children and younger adults. Patients are usually $<40$ years of age, while other GISTs are rarely seen in younger individuals. SDH-deficient GISTs account for two-thirds of cases in the 20-29 age group and are more common in females (16). Lesions are almost always located in the stomach, and the antrum is the most common location, followed by the posterior wall of the stomach and the fundus, and they have a tendency for lymphatic invasion and lymph node metastasis compared with other mutant GIST types (83). Immunohistochemically negative SDHA GISTs are rare in children, are more common in males, and lack of SDHA staining is associated with an increased rate of metastasis to the liver; however, there is no difference in tumor size or mitosis rate (79).

The Carney triad includes GISTs, pulmonary chondromas and extra-adrenal paraganglioma. It was first described as a triad of gastric leiomyosarcoma in 1977, and only few patients exhibit a complete Carney triad. In the majority of cases, only two of these tumors are observed (84). Patients with Carney triad are typically younger women who are susceptible to various tumors, including pheochromocytoma and other non-functional bilateral or unilateral adrenal adenomas. Although the Carney triad-associated GISTs lack mutations in any of the SDH subunits, the function of the SDH complex is still impaired and may be associated with hypermethylation of the SDHC promoter (85).

Carney-Stratakis syndrome, first described in 2002, is a rare hereditary syndrome inherited by autosomal dominant inheritance with incomplete penetrance. It is characterized by multifocal gastric GISTs and multicentric paraganglioma (86). Germline mutations in $S D H B, S D H C, S D H D$ have been identified in patients with Carney-Stratakis syndrome (87) and no mutations in the coding sequence of the SDHA gene have been identified (88).

Upregulation of insulin like growth factor 1 receptor (IGF1R) expression in SDH-deficient tumors is considered to be a feature of SDH-deficient GISTs (89). IGF1R is part of the insulin-like growth factor family of proteins, which consists of two ligands (IGF1 and IGF2), two receptors (IGF1R and IGF2R) and six IGF binding proteins (IGFBPs). Binding of IGF and IGFR activates downstream signaling, including the RAS/RAF/MAPK and PI3K/AKT pathways (Fig. 3C) (90). Dysfunction of SDH leads to the accumulation of succinic acid, which in turn inhibits the activity of proline hydroxylase, resulting in the accumulation of HIF1 $\alpha$, translocation of HIF $1 \alpha$ to the nucleus and dimerization of HIF1 $\beta$ to form an active transcription factor that induces expression of glycolytic and angiogenic genes (including IGF and VEGF), which in turn promotes cell proliferation via the RAS/RAF/MAPK and PI3K/AKT signaling pathways (57,91-93). IGF1R expression has been observed in $88.75 \%$ of SDH-deficient GISTs, whereas only in $1 \%$ of SDHB-positive patients. Thus detection of IGF1R can help to identify SDH defective GISTs. IGF1 has been shown to promote cell proliferation in vitro. Animal experiments have shown that inhibiting IGF signaling reduced tumor growth (94). Epidemiological evidence suggests that IGF1 levels are associated with cancer risk and prognosis (95). At present, upregulation of IGF1R is observed in a number of different types of cancer. Because of its role in the metabolism of cancer cells and its potential correlation with the survival of malignant cells, IGF1R has become a target of anticancer therapy (96-98). In a phase I clinical trial, patients with 
solid tumors were treated with IGF1R monoclonal antibody R1507 (also known as RO4858696) and chemotherapeutics or targeted drugs. One of these patients did not receive the full treatment, but the partial response to the disease reached 3 years (99). However, the complexity of the IGF1R pathway and its interaction with other signaling pathways has not been fully elucidated. Further preclinical research is required to understand the complex mechanisms to develop improved therapeutic options.

Non-SDH-deficient GISTs. Non-SDH-deficient GISTs include NF1 correlation, BRAF mutation, RAS gene mutation and quadruple wild-type. GISTs with BRAF/RAS or NF1 mutations can be collectively called RAS pathway-mutant GISTs. The demographic characteristics of non-SDH-deficient GISTs are similar to those of KIT/PDGFRA-mutant GISTs, and are more frequently observed in adults and primary exhibit a spindle-cell morphology (100). However, unlike KIT/PDGFRA-mutant GISTs, non-SDH-deficient wild-type GIST are primarily located in the small intestine.

NF1 gene mutation. NF1, also known as von Recklinghausen disease, is an inherited cancer susceptibility syndrome, caused by a biallelic deletion of the NFl gene and is characterized by neurological, cutaneous and skeletal lesions. It is one of the most common genetic syndromes with an incidence of 1/2,500-3,000 individuals (101). Patients with NF1 type have a higher risk of developing GISTs, and $~ 7 \%$ of NF1 patients have concurrent GISTs, which is considerably higher than the normal population (102). Patients with NF1-related GISTs are usually younger, and the lesions are primarily located in the duodenum and small intestine and exhibit a slower clinical progression. However, $15-20 \%$ of patients with NF1-related GISTs exhibit malignant clinical outcomes. The tumors are small in size, with a high positive rate of CD117 and CD34 expression. Tumor tissues are composed of cells with a spindle-cell like morphology, with a low mitotic rate $(100,103)$.

The neurofibromin protein encoded by the NF1 gene regulates the RAS signaling pathway by catalytically activating Ras-GTP hydrolysis to inactive Ras-GDP. Mutation of the NFl gene results in loss of neurofibromin function leading to constitutive activation of RAS, which increases downstream signaling of receptors via the MAPK pathway. This is considered to be an important mechanism for the pathogenesis of NF1-related GISTs (103). Unlike common GISTs, the JAK-STAT3 and PI3K-AKT pathways are less active in NF1-related GISTs (102). NF1-related GISTs do not respond well to imatinib (104); however, there have been reports of therapeutic response to sunitinib (105). Given that NF1-related GISTs increases signaling through the MAPK pathway, this increases the likelihood of treatment with MEK inhibitors.

BRAF gene mutations. The BRAF (B-Raf proto-oncogene, serine/threonine kinase) gene encodes serine/threonine protein kinases which belong to the RAF family. These kinases serve a role in regulating the MAPK/ERK signaling pathway and can affect cell cycle progression, cell division and differentiation (106). Pathogenic mutations in the BRAF gene cause the
RAF protein to be constitutively activated, resulting in uncontrolled cell growth and proliferation. Additionally, BRAF mutations cooperate with Raclb, AKT3 and other signaling molecules, which also promote the viability and proliferation of cancer cells (107). BRAF mutations are observed in many benign and malignant tumors, such as benign congenital and acquired melanocytic nevus, malignant melanoma, papillary thyroid cancer, non-small cell lung cancer and colorectal adenoma (108).

$B R A F$ gene mutations account for $\sim 4 \%$ of the wild-type GISTs, and the most common mutation is V600E of exon 15, and the BRAF V600E site mutation is considered to be exclusive of KIT and PDGFRA mutations (109). Hostein et al (110) analyzed GIST pathology from the Bergonie Institute from 2004 to 2008 and found that the lesions of GISTs with BRAF mutations were mostly located in the small intestine $(5 / 9 ; 56 \%)$, followed by the stomach $(2 / 9 ; 22 \%)$. There was no significant association between tumor location, tumor size and mitosis between wild-type GISTs with or without BRAF mutations. However, the sample size in this study was too small, thus the results may not be reliable. MEK inhibitors and RAF inhibitors are used to inhibit pathogenic consequences of mutations of BRAF. MEK inhibitors inhibit the downstream MEK protein of BRAF, while RAF inhibitors inhibit the active RAF protein to control the uncontrolled MAPK/ERK signaling pathway. Currently, the FDA approved MEK inhibitors include trametinib and cobimetinib, while RAF inhibitors are dabrafenib and vemurafenib. Patients with BRAF mutations in GISTs have a longer overall survival and a better clinical outcome (111).

RAS gene mutation. The RAS protein acts as a molecular switch that switches between its active GTP binding state and inactive GDP binding state. The majority of RAS mutations are observed in codons 12,13 or 61. Mutations of the RAS gene or its regulatory factors cause the RAS protein to remain active, leading to tumorigenesis. Activated alleles of HRAS, NRAS and KRAS have been shown to possess a similar phenotype to activated BRAF, CRAF, MEK1 or MEK2-driven alleles in human tumors (112). Miranda et al (113) identified codon 12 (G12D) and codon 13 (G13D) mutations in the KRAS gene in $\sim 5 \%$ of patients with GISTs. G12D-mutant tumors are accompanied by deletion mutations in KIT exon 11 (570-576 and 579), whereas patients with G13D mutations are accompanied by PDGFRA gene D842V mutation. Additionally, KRAS and BRAF mutations may affect the response of imatinib-sensitive KIT mutants to imatinib therapy, thus it was suggested that KRAS and BRAF mutation analysis should be introduced in clinical diagnosis of patients with GISTs.

Quadruple wild-type GISTs. Quadruple wild-type GISTs are not associated with SDH mutations, BRAF mutations or RAS mutations (114). Nannini et al (115) analyzed the genome of patients with quadruple wild-type GISTs and found that they had significantly different genome profiles from KIT/PDGFR mutation or SDH-deficient GISTs. Molecular markers CALCRL and COL22A1, and specific oncogenes, including NTRK2 and CDK6, and ETS were found in both small intestine quadruple wild-type GISTs. Brenca et al (116) found an ETV6-NTRK3 fusion in a patient with rectal 
Table I. Characteristics of each molecular subtype of GISTs.

\begin{tabular}{|c|c|c|c|c|c|}
\hline Subtype & $\begin{array}{l}\text { Genetic } \\
\text { alteration }\end{array}$ & Mutation & Frequency & Localization & Features \\
\hline \multirow[t]{4}{*}{ KIT $(70-80 \%)$} & Exon $11(\mathrm{JM})$ & $\begin{array}{l}\text { W557-K558_del } \\
\text { V559_del V575A }\end{array}$ & $70-80 \%$ & Whole GI tract & $\begin{array}{l}\text { Malignant potential Imatinib } \\
\text { (responsive) }\end{array}$ \\
\hline & Exon 9 (EC) & $\begin{array}{l}\text { Insertion } \\
\text { AY502-503 }\end{array}$ & $10 \%$ & $\begin{array}{l}\text { Small intestine } \\
\text { and colon }\end{array}$ & $\begin{array}{l}\text { Higher recurrence and } \\
\text { metastasis rates; Imatinib } \\
\text { (partially resistant) Sunitinib } \\
\text { (responsive) }\end{array}$ \\
\hline & Exon1 3 (TK I) & K642E & $1 \%$ & Whole GI tract & $\begin{array}{l}\text { Secondary mutations; Imatinib } \\
\text { (responsive) }\end{array}$ \\
\hline & Exon 17 (TK II) & N822K D816V & $1 \%$ & Whole GI tract & $\begin{array}{l}\text { Secondary mutations (30-40\%); } \\
\text { Imatinib or } \\
\text { sunitinib resistant; Regorafenib } \\
\text { (responsive) }\end{array}$ \\
\hline \multirow[t]{3}{*}{ PDGFRA (10-15\%) } & Exon 12 (JM) & V561A & & Stomach & Imatinib (responsive) \\
\hline & Exon 14 (TK I) & N659Y N659K & $<1 \%$ & & $\begin{array}{l}\text { Imatinib (responsive) } \\
\text { Relatively good prognosis; }\end{array}$ \\
\hline & Exon 18 (TK II) & $\begin{array}{l}\text { D824V, D842Y } \\
\text { (I843_del } \\
\text { I843-H845_del } \\
\text { I843_del } \\
\text { I843-H845_del } \\
\text { D842-H845_del } \\
\text { D842-M844_del } \\
\text { D842-H845_del } \\
\text { D842-M844_del) }\end{array}$ & $5 \%$ & Whole GI tract & $\begin{array}{l}\text { Imatinib resistant; avapratinib, } \\
\text { crenolanib responsive; }\end{array}$ \\
\hline SDH-deficient GISTs & & SDHx mutation & $\approx 5 \%$ & Stomach & $\begin{array}{l}\text { Children and young adults } \\
\text { Female predilection; High rate } \\
\text { of liver metastasis; } \\
\text { Overexpression of IGF1R; } \\
\text { Imatinib resistant }\end{array}$ \\
\hline \multirow[t]{3}{*}{$\begin{array}{l}\text { Non-SDH-deficient } \\
\text { GISTs }\end{array}$} & & NF1 & $<1 \%$ & $\begin{array}{l}\text { Generally } \\
\text { duodenum and } \\
\text { small intestine }\end{array}$ & $\begin{array}{l}\text { Younger age; High positive } \\
\text { rates of CD117 and CD34; } \\
\text { Imatinib resistant }\end{array}$ \\
\hline & Exon 15 & BRAF (V600E) & $\approx 4 \%$ & Unknown & $\begin{array}{l}\text { Longer overall survival and } \\
\text { better clinical outcome; } \\
\text { Imatinib resistant }\end{array}$ \\
\hline & KRAS & G12D G13D & $\approx 5 \%$ & Unknown & $\begin{array}{l}\text { May affect the response of } \\
\text { imatinib-sensitive KIT mutants } \\
\text { to imatinib therapy }\end{array}$ \\
\hline $\begin{array}{l}\text { Quadruple } \\
\text { wild-type GISTs }\end{array}$ & & $\begin{array}{l}\text { ETV6-NTRK3 } \\
\text { FGFR1-HOOK3 } \\
\text { FGFR1-TACC1 } \\
\text { Somatic gene } \\
\text { mutations (TP53, } \\
\text { MEN1, MAX, } \\
\text { FGFR1, CTNND2, } \\
\text { CHD4) }\end{array}$ & Unknown & Unknown & $\begin{array}{l}\text { Activation of IGF1R } \\
\text { signaling }\end{array}$ \\
\hline
\end{tabular}

GISTs, gastrointestinal stromal tumors; KIT, KIT proto-oncogene, receptor tyrosine kinase; PDGFRA, platelet derived growth factor receptor $\alpha$; JM, juxtamembrane; EC, extracellular domain; TK, TKI domain (ATP-binding pocket); TKII, TKII domain (activation loop); SDH, succinate dehydrogenase; NF1, neurofibromatosis type 1; GI, gastrointestinal. 
quadruple wild-type GISTs. Shi et al (117) found a fusion of the FGFR1 gene (FGFR1-HOOK3 and FGFR1-TACC1) in quadruple wild-type GISTs. NF1 gene inactivation was also observed in quadruple wild-type GISTs, but the patient did not show neurofibromatosis type 1 symptoms (118). In addition, somatic gene mutations such as TP53, MEN1, MAX, FGFR1, CTNND2 and CHD4 were found in quadruple wild-type GISTs (119). These findings may assist in the identification of new therapeutic targets. In vitro experiments indicate that ETV6-NTRK3 fusion is associated with activation of downstream IGF1R signaling and that tumor cells are susceptible to IGF1R inhibition. In addition, ALK inhibitors, a target drug for ETV6-NTRK3 gene fusion, have shown therapeutic potential (116). The Murine double-minute 2 inhibitor can inhibit the growth of TP53 wild-type GIST cells and enhance the therapeutic response of GIST cells to TKI. This suggests that the regulation of the $\mathrm{p} 53$ gene may be a potential effective therapeutic strategy (120).

\section{6. ctDNA and GISTs}

Extracellular DNA fragments in different body fluids (plasma, serum, urine, and saliva) are referred to as cell free DNA (cfDNA). The primary part of cfDNA in the blood is adsorbed to the surface of white blood cells or red blood cells, and its half-life is short because it is easily degraded by nucleases $(121,122)$. Among these, cfDNA derived from tumor cells is called ctDNA, which may be produced by apoptosis or necrosis of cancer cells (123). cfDNA is primarily composed of ctDNA, and normal extracellular DNA accounts for only a small portion of cfDNA $(124,125)$. The feasibility report of plasma-based ctDNA analysis for tumors in GISTs was first published at the ASCO annual meeting in 2013. The report showed that the consistency of mutations in exon 9 and 11 of KIT between tumor tissue and plasma was $84 \%$. In particular, the consistency of KIT mutations of exon 9 was $100 \%$, whereas that of KIT exon 11 was only $79 \%$. It is also noteworthy that a higher KIT mutation rate $47 \%$ vs. $12 \%$ ) was detected in plasma by BEAMing compared with tumor tissue (13). Maier et al (126) subsequently confirmed the presence of KIT/PDGFRA mutant ctDNA in the plasma, and the quantity of mutant ctDNA was associated with the clinical course of the disease. Namløs et al (127) found that the detection rate of tumor ctDNA mutations in the plasma of high-risk patients or patients with metastatic diseases was higher compared with patients with localized, or moderate- or low-risk GISTs. Jilg et al (128) confirmed that tumor-specific KIT and PDGFRA mutations could be detected in the ctDNA of patients with active GISTs and were positively correlated with disease activity. Other mutations indicating disease progression, including BRAF, NRAS, PIK3CA, PTEN and CTNNB1 mutations, are found in ctDNA, which can influence treatment regimens. All the above studies have demonstrated that ctDNA detection in plasma has important guiding significance for the diagnosis and prognosis of GISTs. However, liquid biopsy technology as a complement to other commonly used clinical techniques still has many limitations, and it is far from ready for use in clinical practice; however, the prospects of this technology is promising.

\section{Non-coding RNAs and GISTs}

Non-coding RNA refers to RNA that does not encode proteins. It has been found that various miRNAs and lncRNAs are associated with the occurrence and development of GISTs.

MicroRNAs (miRNAs) are small non-coding RNAs which participate in the regulation of post-transcriptional gene expression (129). Dysregulation of various miRNAs has been identified in many different types of cancer, including gastric cancer (130), colorectal cancer (131), pancreatic cancer (132), and childhood glioma (133). miRNAs regulate target gene expression by acting on key molecular pathways and mediate cell invasion, migration, proliferation, apoptosis and drug resistance. A German study found that miR-221 and miR-222 were downregulated in wild-type and mutant GISTs, and in vitro experiments, they confirmed that the expression of these miRNAs induced apoptosis through a KIT/AKT/BCL2 signaling pathway (134). miR-17 (135), miR-20a (135), miR-21 (136), miR-133b (137), miR-137 (138), miR-152 (139), miR-218 (140), miR-494 (141), miR-518a (117), have all been confirmed to be downregulated in GISTs. Overexpression of miR-218 also inhibits the PI3K/AKT pathway and thereby increases the sensitivity of GIST cells to imatinib (140). Conversely, miR-125a and miR-196a were found to be upregulated in GISTs. Overexpression of miR-125a is associated with imatinib resistance (142). Overexpression of miR-196a increases the invasiveness of cancer cells (143) , and is associated with high risk classification, a high rate of metastasis and reduced survival rates (144). In addition, studies have shown that circulating miRNAs can be used as biomarkers for detection of various types of malignant tumors, including gastric cancer (145), colorectal cancer (146), and pancreatic cancer (147). Serum circulating miR-518e-5p has been found to be a potential non-invasive biomarker for early detection and diagnosis of secondary imatinib-resistant GISTs (148).

lncRNAs works by interacting with other cellular molecules, including DNA, RNA binding protein and RNA. IncRNAs serve an important role in the diagnosis, monitoring, prognosis and evaluation of therapeutic reactivity of tumors (149). HOTAIR is one of the most widely studied carcinogenic lncRNAs. Overexpression of HOTAIR is associated with an increase in invasiveness of GIST cells and knockdown of HOTAIR can inhibit the invasiveness of GIST cells (143). HOTAIR also regulates the progression of GISTs by inducing methylation of the promoter of the pro-cadherin 10 gene in GIST cells (11). HOTAIR is upregulated in invasive GISTs and mediates gene-specific DNA methylation. This further confirms the role of HOTAIR in GISTs (150). Yan et al (151) confirmed that CCDC26 enhances the sensitivity of imatinib by downregulating IGF-1R expression, and showed that CCDC26 may be used as a therapeutic target to reverse imatinib resistance in patients with GISTs.

\section{Conclusion}

The progress made in the field of molecular biology in the past 20 years has provided a deeper understanding of the pathogenesis of GISTs. The characteristics of each molecular subtype are summarized in Table I. Receptor TKIs currently used to treat patients with GISTs are based on these subtypes and the use of these drugs significantly prolong life 
expectancy. Nevertheless, resistance to second-line therapeutics is becoming increasingly common. Additionally, there is no specific treatment for patients with wild-type GISTs. Thus an improved understanding is required to further understand the molecular mechanisms underlying the different subtypes of GISTs to develop improved therapeutic options.

\section{Acknowledgements}

Not applicable.

\section{Funding}

The present study was supported by the Science and Technology Projects of Zhejiang Province (LGF19H030007), the Traditional Chinese Medicine Science and Technology Project of Zhejiang Province (2018ZA109), the Natural Science Foundation of Ningbo (2016A610157 and 2018A610371), the Medical Science and Technology Project of Zhejiang Province (2020KY813) and the Medical and Health Science and Technology Project of Zhejiang Province (2018ZH026).

\section{Availability of data and materials}

The datasets used during the present study are available from the corresponding author upon reasonable request.

\section{Authors' contributions}

HD and ZY conceived and designed the study and prepared the manuscript. XY, YY, XL and $\mathrm{CH}$ were responsible for the literature search, data visualization and analysis. KG and YJ retrieved the relevant literature and revised the manuscript. All authors read and approved the final manuscript.

\section{Ethics approval and consent to participate}

Not applicable.

\section{Patient consent for publication}

Not applicable.

\section{Competing interests}

The authors declare that they have no competing interests.

\section{References}

1. Søreide K, Sandvik OM, Søreide JA, Giljaca V, Jureckova A and Bulusu VR: Global epidemiology of gastrointestinal stromal tumours (GIST): A systematic review of population-based cohort studies. Cancer Epidemiol 40: 39-46, 2016.

2. Miettinen M, Sobin LH and Lasota J: Gastrointestinal stromal tumors of the stomach: A clinicopathologic, immunohistochemical, and molecular genetic study of 1765 cases with long-term follow-up. Am J Surg Pathol 29: 52-68, 2005.

3. Briggler AM, Graham RP, Westin GF, Folpe AL, Jaroszewski DE, Okuno SH and Halfdanarson TR: Clinicopathologic features and outcomes of gastrointestinal stromal tumors arising from the esophagus and gastroesophageal junction. J Gastrointest Oncol 9: 718-727, 2018.
4. Emile JF, Brahimi S, Coindre JM, Bringuier PP, Monges G, Samb P, Doucet L, Hostein I, Landi B, Buisine MP, et al: Frequencies of KIT and PDGFRA mutations in the MolecGIST prospective population-based study differ from those of advanced GISTs. Med Oncol 29: 1765-1772, 2012.

5. Agaimy A and Wünsch PH: Lymph node metastasis in gastrointestinal stromal tumours (GIST) occurs preferentially in young patients < or $=40$ years: An overview based on our case material and the literature. Langenbecks Arch Surg 394: 375-381, 2009.

6. Zhang L, Smyrk TC, Young WF Jr, Stratakis CA and Carney JA: Gastric stromal tumors in Carney triad are different clinically, pathologically, and behaviorally from sporadic gastric gastrointestinal stromal tumors: Findings in 104 cases. Am J Surg Pathol 34: 53-64, 2010.

7. Pink D, Schoeler D, Lindner T, Thuss-Patience PC, Kretzschmar A, Knipp H, Vanhoefer U and Reichardt P: Severe hypoglycemia caused by paraneoplastic production of IGF-II in patients with advanced gastrointestinal stromal tumors: A report of two cases. J Clin Oncol 23: 6809-6811, 2005.

8. Maynard MA and Huang SA: Thyroid hormone inactivation in gastrointestinal stromal tumors. N Engl J Med 371: 86-87, 2014.

9. Duensing A, Medeiros F, McConarty B, Joseph NE, Panigrahy D, Singer S, Fletcher CD, Demetri GD and Fletcher JA: Mechanisms of oncogenic KIT signal transduction in primary gastrointestinal stromal tumors (GISTs). Oncogene 23: 3999-4006, 2004.

10. Ricci R: Syndromic gastrointestinal stromal tumors. Hered Cancer Clin Pract 14: 15, 2016.

11. Lee NK, Lee JH, Kim WK, Yun S, Youn YH, Park CH, Choi YY, Kim H and Lee SK: Promoter methylation of PCDH10 by HOTAIR regulates the progression of gastrointestinal stromal tumors. Oncotarget 7: 75307-75318, 2016.

12. Kupcinskas J: Small molecules in rare tumors: Emerging role of microRNAs in GIST. Int J Mol Sci 19: 19, 2018.

13. Demetri GD, Jeffers M and Reichardt PG: Mutational analysis of plasma DNA from patients (pts) in the phase III GRID study of regorafenib (REG) versus placebo (PL) in tyrosine kinase inhibitor (TKI)-refractory GIST: Correlating genotype with clinical outcomes. Oncol Res Treat 37: 58-58, 2013.

14. Nilsson B, Bümming P, Meis-Kindblom JM, Odén A, Dortok A, Gustavsson B, Sablinska K and Kindblom LG: Gastrointestinal stromal tumors: The incidence, prevalence, clinical course, and prognostication in the preimatinib mesylate era-a population-based study in western Sweden. Cancer 103: 821-829, 2005.

15. Joensuu H, Vehtari A, Riihimäki J, Nishida T, Steigen SE, Brabec P, Plank L, Nilsson B, Cirilli C, Braconi C, et al: Risk of recurrence of gastrointestinal stromal tumour after surgery: An analysis of pooled population-based cohorts. Lancet Oncol 13: 265-274, 2012.

16. Janeway KA, Kim SY, Lodish M, Nosé V, Rustin P, Gaal J, Dahia PL, Liegl B, Ball ER, Raygada M, et al: NIH pediatric and wild-type GIST clinic: Defects in succinate dehydrogenase in gastrointestinal stromal tumors lacking KIT and PDGFRA mutations. Proc Natl Acad Sci USA 108: 314-318, 2011.

17. Broudy VC, Lin NL and Sabath DF: The fifth immunoglobulin-like domain of the Kit receptor is required for proteolytic cleavage from the cell surface. Cytokine 15: 188-195, 2001.

18. Hanks SK, Quinn AM and Hunter T: The protein kinase family: Conserved features and deduced phylogeny of the catalytic domains. Science 241: 42-52, 1988

19. Lennartsson J and Rönnstrand L: Stem cell factor receptor/c-Kit: From basic science to clinical implications. Physiol Rev 92: 1619-1649, 2012.

20. Roskoski R Jr: Signaling by Kit protein-tyrosine kinase-the stem cell factor receptor. Biochem Biophys Res Commun 337: 1-13, 2005.

21. Lennartsson J, Blume-Jensen P, Hermanson M, Pontén E, Carlberg M and Rönnstrand L: Phosphorylation of Shc by Src family kinases is necessary for stem cell factor receptor/c-kit mediated activation of the Ras/MAP kinase pathway and c-fos induction. Oncogene 18: 5546-5553, 1999.

22. Rotert JV, Leupold J, Hohenberger P, Nowak K and Allgayer H Src activity is increased in gastrointestinal stromal tumors-analysis of associations with clinical and other molecular tumor characteristics. J Surg Oncol 109: 597-605, 2014.

23. Serve H, Hsu YC and Besmer P: Tyrosine residue 719 of the c-kit receptor is essential for binding of the P85 subunit of phosphatidylinositol (PI) 3-kinase and for c-kit-associated PI 3-kinase activity in COS-1 cells. J Biol Chem 269: 6026-6030, 1994. 
24. Sun J, Pedersen M and Rönnstrand L: Gab2 is involved in differential phosphoinositide 3-kinase signaling by two splice forms of c-Kit. J Biol Chem 283: 27444-27451, 2008.

25. Deberry C, Mou S and Linnekin D: Stat1 associates with c-kit and is activated in response to stem cell factor. Biochem J 327: 73-80, 1997.

26. Brizzi MF, Blechman JM, Cavalloni G, Givol D, Yarden Y and Pegoraro L: Protein kinase C-dependent release of a functional whole extracellular domain of the mast cell growth factor (MGF) receptor by MGF-dependent human myeloid cells. Oncogene 9: 1583-1589, 1994.

27. Heinrich MC, Patterson J,Beadling C, Wang Y,Debiec-Rychter M Dewaele B, Corless CL, Duensing A, Raut CP, Rubin B, et al: Genomic aberrations in cell cycle genes predict progression of KIT-mutant gastrointestinal stromal tumors (GISTs). Clin Sarcoma Res 9: 3, 2019.

28. Hirota S, Isozaki K, Moriyama Y, Hashimoto K, Nishida T, Ishiguro S, Kawano K, Hanada M, Kurata A, Takeda M, et al: Gain-of-function mutations of c-kit in human gastrointestinal stromal tumors. Science 279: 577-580, 1998.

29. Kinoshita K, Isozaki K, Hirota S, Nishida T, Chen H, Nakahara M, Nagasawa Y, Ohashi A, Shinomura Y, Kitamura Y and Matsuzawa Y: c-kit gene mutation at exon 17 or 13 is very rare in sporadic gastrointestinal stromal tumors. J Gastroenterol Hepatol 18: 147-151, 2003.

30. Rubin BP, Singer S, Tsao C, Duensing A, Lux ML, Ruiz R, Hibbard MK, Chen CJ, Xiao S, Tuveson DA, et al: KIT activation is a ubiquitous feature of gastrointestinal stromal tumors. Cancer Res 61: 8118-8121, 2001.

31. Heinrich MC, Corless CL, Demetri GD, Blanke CD, von Mehren M, Joensuu H, McGreevey LS, Chen CJ, Van den Abbeele AD, Druker BJ, et al: Kinase mutations and imatinib response in patients with metastatic gastrointestinal stromal tumor. J Clin Oncol 21: 4342-4349, 2003.

32. Xu CW, Lin S, Wang WL, Gao WB, Lv JY, Gao JS, Zhang LY, Li Y, Wang L, Zhang YP and Tian YW: Analysis of mutation of the c-Kit gene and PDGFRA in gastrointestinal stromal tumors. Exp Ther Med 10: 1045-1051, 2015.

33. Martín J, Poveda A, Llombart-Bosch A, Ramos R, LópezGuerrero JA, García del Muro J, Maurel J, Calabuig S, Gutierrez A, González de Sande JL, et al; Spanish Group for Sarcoma Research: Deletions affecting codons 557-558 of the c-KIT gene indicate a poor prognosis in patients with completely resected gastrointestinal stromal tumors: A study by the Spanish Group for Sarcoma Research (GEIS). J Clin Oncol 23: 6190-6198, 2005.

34. Wardelmann E, Losen I, Hans V, Neidt I, Speidel N, Bierhoff E, Heinicke T, Pietsch T, Büttner R and Merkelbach-Bruse S: Deletion of Trp-557 and Lys-558 in the juxtamembrane domain of the c-kit protooncogene is associated with metastatic behavior of gastrointestinal stromal tumors. Int J Cancer 106: 887-895, 2003.

35. Singer S, Rubin BP, Lux ML, Chen CJ, Demetri GD, Fletcher CD and Fletcher JA: Prognostic value of KIT mutation type, mitotic activity, and histologic subtype in gastrointestinal stromal tumors. J Clin Oncol 20: 3898-3905, 2002.

36. Wozniak A, Rutkowski P, Schöffski P, Ray-Coquard I, Hostein I, Schildhaus HU, Le Cesne A, Bylina E, Limon J, Blay JY, et al: Tumor genotype is an independent prognostic factor in primary gastrointestinal stromal tumors of gastric origin: A European Multicenter Analysis based on ConticaGIST. Clin Cancer Res 20 6105-6116, 2014

37. Quek R, Farid M, Kanjanapan Y, Lim C, Tan IB, Kesavan S, Lim TKH, Oon LL, Goh BK, Chan WH, et al: Prognostic significance of KIT exon 11 deletion mutation in intermediate-risk gastrointestinal stromal tumor. Asia Pac J Clin Oncol 13: $115-124,2017$

38. Debiec-Rychter M, Dumez H, Judson I, Wasag B, Verweij J, Brown M, Dimitrijevic S, Sciot R, Stul M, Vranck H, et al: Use of c-KIT/PDGFRA mutational analysis to predict the clinical response to imatinib in patients with advanced gastrointestinal stromal tumours entered on phase I and II studies of the EORTC soft tissue and bone sarcoma group. Eur J Cancer 40: 689-695, 2004

39. Antonescu CR, Sommer G, Sarran L, Tschernyavsky SJ, Riedel E, Woodruff JM, Robson M, Maki R, Brennan MF, Ladanyi M, et al: Association of KIT exon 9 mutations with nongastric primary site and aggressive behavior: KIT mutation analysis and clinical correlates of 120 gastrointestinal stromal tumors. Clin Cancer Res 9: 3329-3337, 2003.
40. Wozniak A, Rutkowski P, Piskorz A, Ciwoniuk M, Osuch C, Bylina E, Sygut J, Chosia M, Rys J, Urbanczyk K, et al: Prognostic value of KIT/PDGFRA mutations in gastrointestinal stromal tumours (GIST): Polish clinical GIST registry experience. Ann Oncol 23: 353-360, 2012.

41. Lasota J, Wozniak A, Sarlomo-Rikala M, Rys J, Kordek R, Nassar A, Sobin LH and Miettinen M: Mutations in exons 9 and 13 of KIT gene are rare events in gastrointestinal stromal tumors. A study of 200 cases. Am J Pathol 157: 1091-1095, 2000.

42. Sakurai S, Oguni S, Hironaka M, Fukayama M, Morinaga S and Saito K: Mutations in c-kit gene exons 9 and 13 in gastrointestinal stromal tumors among Japanese. Jpn J Cancer Res 92: 494-498, 2001

43. Künstlinger H, Huss S, Merkelbach-Bruse S, Binot E, Kleine MA, Loeser H, Mittler J, Hartmann W, Hohenberger P, Reichardt P, et al: Gastrointestinal stromal tumors with KIT exon 9 mutations: Update on genotype-phenotype correlation and validation of a high-resolution melting assay for mutational testing. Am J Surg Pathol 37: 1648-1659, 2013.

44. Mulet-Margalef N and Garcia-Del-Muro X: Sunitinib in the treatment of gastrointestinal stromal tumor: Patient selection and perspectives. Onco Targets Ther 9: 7573-7582, 2016.

45. Yeh CN, Chen TW, Tseng JH, Liu YY, Wang SY, Tsai CY, Chiang KC, Hwang TL, Jan YY and Chen MF: Surgical management in metastatic gastrointestinal stromal tumor (GIST) patients after imatinib mesylate treatment. J Surg Oncol 102: 599-603, 2010.

46. Gao J, Tian Y, Li J, Sun N, Yuan J and Shen L: Secondary mutations of c-KIT contribute to acquired resistance to imatinib and decrease efficacy of sunitinib in Chinese patients with gastrointestinal stromal tumors. Med Oncol 30: 522, 2013.

47. Yeh CN, Chen MH, Chen YY, Yang CY, Yen CC, Tzen CY, Chen LT and Chen JS: A phase II trial of regorafenib in patients with metastatic and/or a unresectable gastrointestinal stromal tumor harboring secondary mutations of exon 17. Oncotarget 8 : 44121-44130, 2017

48. Mazzocca A, Napolitano A, Silletta M, Spalato Ceruso M, Santini D, Tonini G and Vincenzi B: New frontiers in the medical management of gastrointestinal stromal tumours. Ther Adv Med Oncol 11: 1758835919841946, 2019.

49. Lasota J, Corless CL, Heinrich MC, Debiec-Rychter M, Sciot R, Wardelmann E, Merkelbach-Bruse S, Schildhaus HU, Steigen SE, Stachura J, et al: Clinicopathologic profile of gastrointestinal stromal tumors (GISTs) with primary KIT exon 13 or exon 17 mutations: A multicenter study on 54 cases. Mod Pathol 21: 476-484, 2008

50. Lux ML, Rubin BP, Biase TL, Chen CJ, Maclure T, Demetri G, Xiao S, Singer S, Fletcher CD and Fletcher JA: KIT extracellular and kinase domain mutations in gastrointestinal stromal tumors. Am J Pathol 156: 791-795, 2000.

51. Ning ZQ, Li J and Arceci RJ: Activating mutations of c-kit at codon 816 confer drug resistance in human leukemia cells. Leuk Lymphoma 41: 513-522, 2001.

52. Nagata $\mathrm{H}$, Worobec AS, Oh CK, Chowdhury BA, Tannenbaum $\mathrm{S}$, Suzuki Y and Metcalfe DD: Identification of a point mutation in the catalytic domain of the protooncogene c-kit in peripheral blood mononuclear cells of patients who have mastocytosis with an associated hematologic disorder. Proc Natl Acad Sci USA 92: 10560-10564, 1995.

53. Tian Q, Frierson HF Jr, Krystal GW and Moskaluk CA: Activating c-kit gene mutations in human germ cell tumors. Am J Pathol 154: 1643-1647, 1999.

54. Hongyo T, Li T, Syaifudin M, Baskar R, Ikeda H, Kanakura Y, Aozasa K and Nomura T: Specific c-kit mutations in sinonasal natural killer/T-cell lymphoma in China and Japan. Cancer Res 60: 2345-2347, 2000.

55. Sakuma Y, Sakurai S, Oguni S, Satoh M, Hironaka M and Saito K: c-kit gene mutations in intracranial germinomas. Cancer Sci 95: 716-720, 2004

56. Heinrich MC, Corless CL, Duensing A, McGreevey L, Chen CJ, Joseph N, Singer S, Griffith DJ, Haley A, Town A, et al: PDGFRA activating mutations in gastrointestinal stromal tumors. Science 299: 708-710, 2003.

57. Joensuu H, Hohenberger P and Corless CL: Gastrointestinal stromal tumour. Lancet 382: 973-983, 2013.

58. Wardelmann E, Hrychyk A, Merkelbach-Bruse S, Pauls K, Goldstein J, Hohenberger P, Losen I, Manegold C, Büttner R and Pietsch T: Association of platelet-derived growth factor receptor alpha mutations with gastric primary site and epithelioid or mixed cell morphology in gastrointestinal stromal tumors. J Mol Diagn 6: 197-204, 2004 
59. Debiec-Rychter M, Wasag B, Stul M, De Wever I, Van Oosterom A, Hagemeijer A and Sciot R: Gastrointestinal stromal tumours (GISTs) negative for KIT (CD117 antigen) immunoreactivity. J Pathol 202: 430-438, 2004.

60. Lasota J, Dansonka-Mieszkowska A, Sobin LH and Miettinen M: A great majority of GISTs with PDGFRA mutations represent gastric tumors of low or no malignant potential. Lab Invest 84 : 874-883, 2004

61. Indio V, Astolfi A, Tarantino G, Urbini M, Patterson J, Nannini M, Saponara M, Gatto L, Santini D, do Valle IF, et al: Integrated molecular characterization of gastrointestinal stromal tumors (GIST) harboring the rare D842V mutation in PDGFRA gene. Int J Mol Sci 19: E732, 2018.

62. Heinrich M, von Mehren M, Jones RL, Bauer S, Kang YK, Schöffski P, Eskens F, Serrano C, Cassier PA, Mir O, et al: Avapritinib is highly active and well-tolerated in patients (pts) with advanced GIST driven by diverse variety of oncogenic mutations in KIT and PDGFRA. Presented at: 2018 CTOS Annual Meeting; November 15, 2018 Rome, Italy (abstract 3027631) https://www.blueprintmedicines.com/wp-content/uploads/2019/01/ CTOS-Avapritinib-Update-Nov-2018.pdf.

63. Medeiros F, Corless CL, Duensing A, Hornick JL, Oliveira AM, Heinrich MC, Fletcher JA and Fletcher CD: KIT-negative gastrointestinal stromal tumors: Proof of concept and therapeutic implications. Am J Surg Pathol 28: 889-894, 2004.

64. Lasota $\mathrm{J}$ and Miettinen M: KIT and PDGFRA mutations in gastrointestinal stromal tumors (GISTs). Semin Diagn Pathol 23 91-102, 2006

65. Corless CL, Schroeder A, Griffith D, Town A, McGreevey L, Harrell P, Shiraga S, Bainbridge T, Morich J and Heinrich MC: PDGFRA mutations in gastrointestinal stromal tumors: Frequency, spectrum and in vitro sensitivity to imatinib. J Clin Oncol 23: 5357-5364, 2005.

66. Lasota J, Stachura J and Miettinen M: GISTs with PDGFRA exon 14 mutations represent subset of clinically favorable gastric tumors with epithelioid morphology. Lab Invest 86: 94-100, 2006.

67. Nishida T, Hirota S, Taniguchi M, Hashimoto K, Isozaki K, Nakamura H, Kanakura Y, Tanaka T, Takabayashi A, Matsuda H and Kitamura Y: Familial gastrointestinal stromal tumours with germline mutation of the KIT gene. Nat Genet 19: 323-324, 1998.

68. Beghini A, Tibiletti MG, Roversi G, Chiaravalli AM, Serio G, Capella $\mathrm{C}$ and Larizza L: Germline mutation in the juxtamembrane domain of the kit gene in a family with gastrointestinal stromal tumors and urticaria pigmentosa. Cancer 92: 657-662, 2001.

69. Lasota J and Miettinen M: A new familial GIST identified. Am J Surg Pathol 30: 1342, 2006

70. Robson ME, Glogowski E, Sommer G, Antonescu CR, Nafa K, Maki RG, Ellis N, Besmer P, Brennan M and Offit K: Pleomorphic characteristics of a germ-line KIT mutation in a large kindred with gastrointestinal stromal tumors, hyperpigmentation, and dysphagia. Clin Cancer Res 10: 1250-1254, 2004.

71. Hirota S, Nishida T, Isozaki K, Taniguchi M, Nishikawa K, Ohashi A, Takabayashi A, Obayashi T, Okuno T, Kinoshita K, et al: Familial gastrointestinal stromal tumors associated with dysphagia and novel type germline mutation of KIT gene. Gastroenterology 122: 1493-1499, 2002

72. Hartmann K, Wardelmann E, Ma Y, Merkelbach-Bruse S, Preussner LM, Woolery C, Baldus SE, Heinicke T, Thiele J, Buettner R and Longley BJ: Novel germline mutation of KIT associated with familial gastrointestinal stromal tumors and mastocytosis. Gastroenterology 129: 1042-1046, 2005

73. Chompret A, Kannengiesser C, Barrois M, Terrier P, Dahan P, Tursz T, Lenoir GM and Bressac-De Paillerets B: PDGFRA germline mutation in a family with multiple cases of gastrointestinal stromal tumor. Gastroenterology 126: 318-321, 2004.

74. Astolfi A, Nannini M, Pantaleo MA, Di Battista M, Heinrich MC, Santini D, Catena F, Corless CL, Maleddu A, Saponara M, et al: A molecular portrait of gastrointestinal stromal tumors: An integrative analysis of gene expression profiling and high-resolution genomic copy number. Lab Invest 90: 1285-1294, 2010.

75. Wada R, Arai H, Kure S, Peng WX and Naito Z: 'Wild type' GIST: Clinicopathological features and clinical practice. Pathol Int 66: 431-437, 2016

76. Prakash S, Sarran L, Socci N, DeMatteo RP, Eisenstat J, Greco AM, Maki RG, Wexler LH, LaQuaglia MP, Besmer P and Antonescu CR: Gastrointestinal stromal tumors in children and young adults: A clinicopathologic, molecular, and genomic study of 15 cases and review of the literature. J Pediatr Hematol Oncol 27: 179-187, 2005
77. Janeway KA, Liegl B, Harlow A, Le C, Perez-Atayde A, Kozakewich H, Corless CL, Heinrich MC and Fletcher JA: Pediatric KIT wild-type and platelet-derived growth factor receptor alpha-wild-type gastrointestinal stromal tumors share KIT activation but not mechanisms of genetic progression with adult gastrointestinal stromal tumors. Cancer Res 67: 9084-9088, 2007.

78. Gill AJ, Lipton L, Taylor J, Benn DE, Richardson AL, Frydenberg M, Shapiro J, Clifton-Bligh RJ, Chow CW and Bogwitz M: Germline SDHC mutation presenting as recurrent SDH deficient GIST and renal carcinoma. Pathology 45: 689-691, 2013.

79. Miettinen M, Killian JK, Wang ZF, Lasota J, Lau C, Jones L, WalkerR,Pineda M,Zhu YJ,Kim SY, et al:Immunohistochemical loss of succinate dehydrogenase subunit A (SDHA) in gastrointestinal stromal tumors (GISTs) signals SDHA germline mutation. Am J Surg Pathol 37: 234-240, 2013.

80. Barletta JA and Hornick JL: Succinate dehydrogenase-deficient tumors: Diagnostic advances and clinical implications. Adv Anat Pathol 19: 193-203, 2012.

81. Gill AJ: Succinate dehydrogenase (SDH) and mitochondrial driven neoplasia. Pathology 44: 285-292, 2012.

82. Gaal J, Stratakis CA, Carney JA, Ball ER, Korpershoek E, Lodish MB, Levy I, Xekouki P, van Nederveen FH, den Bakker MA, et al: SDHB immunohistochemistry: A useful tool in the diagnosis of Carney-Stratakis and Carney triad gastrointestinal stromal tumors. Mod Pathol 24: 147-151, 2011.

83. Miettinen M, Wang ZF, Sarlomo-Rikala M, Osuch C, Rutkowski P and Lasota J: Succinate dehydrogenase-deficient GISTs: A clinicopathologic, immunohistochemical, and molecular genetic study of 66 gastric GISTs with predilection to young age. Am J Surg Pathol 35: 1712-1721, 2011.

84. Carney JA, Sheps SG, Go VL and Gordon H: The triad of gastric leiomyosarcoma, functioning extra-adrenal paraganglioma and pulmonary chondroma. N Engl J Med 296: 1517-1518, 1977 .

85. Boikos SA, Pappo AS, Killian JK, LaQuaglia MP, Weldon CB, George S, Trent JC, von Mehren M, Wright JA, Schiffman JD, et al: Molecular subtypes of KIT/PDGFRA wild-type gastrointestinal stromal tumors: A report from the national institutes of health gastrointestinal stromal tumor clinic. JAMA Oncol 2: 922-928, 2016.

86. Carney JA and Stratakis CA: Familial paraganglioma and gastric stromal sarcoma: A new syndrome distinct from the Carney triad. Am J Med Genet 108: 132-139, 2002

87. McWhinney SR, Pasini B and Stratakis CA; International Carney Triad and Carney-Stratakis Syndrome Consortium: Familial gastrointestinal stromal tumors and germ-line mutations. N Engl J Med 357: 1054-1056, 2007

88. Pasini B, McWhinney SR, Bei T, Matyakhina L, Stergiopoulos S, Muchow M, Boikos SA, Ferrando B, Pacak K, Assie G, et al: Clinical and molecular genetics of patients with the Carney-Stratakis syndrome and germline mutations of the genes coding for the succinate dehydrogenase subunits SDHB, SDHC, and SDHD. Eur J Hum Genet 16: 79-88, 2008.

89. Chou A, Chen J, Clarkson A, Samra JS, Clifton-Bligh RJ, Hugh TJ and Gill AJ: Succinate dehydrogenase-deficient GISTs are characterized by IGF1R overexpression. Mod Pathol 25: $1307-1313,2012$

90. LeRoith D and Roberts CT Jr: The insulin-like growth factor system and cancer. Cancer Lett 195: 127-137, 2003.

91. Covello KL and Simon MC: HIFs, hypoxia, and vascular development. Curr Top Dev Biol 62: 37-54, 2004.

92. Pugh CW and Ratcliffe PJ: Regulation of angiogenesis by hypoxia: Role of the HIF system. Nat Med 9: 677-684, 2003.

93. Lasota J, Wang Z, Kim SY, Helman L and Miettinen M: Expression of the receptor for type I insulin-like growth factor (IGF1R) in gastrointestinal stromal tumors: An immunohistochemical study of 1078 cases with diagnostic and therapeutic implications. Am J Surg Pathol 37: 114-119, 2013.

94. Wu Y, Cui K, Miyoshi K, Hennighausen L, Green JE, Setser J, LeRoith D and Yakar S: Reduced circulating insulin-like growth factor I levels delay the onset of chemically and genetically induced mammary tumors. Cancer Res 63: 4384-4388, 2003.

95. Gallagher EJ and LeRoith D: Minireview: IGF, insulin, and cancer. Endocrinology 152: 2546-2551, 2011

96. Gotlieb WH, Bruchim I, Gu J, Shi Y, Camirand A, Blouin MJ, Zhao Y and Pollak MN: Insulin-like growth factor receptor I targeting in epithelial ovarian cancer. Gynecol Oncol 100: 389-396, 2006 
97. Sarfstein R, Maor S, Reizner N, Abramovitch S and Werner H: Transcriptional regulation of the insulin-like growth factor-I receptor gene in breast cancer. Mol Cell Endocrinol 252 241-246, 2006.

98. Wu JD, Haugk K, Woodke L, Nelson P, Coleman I and Plymate SR: Interaction of IGF signaling and the androgen receptor in prostate cancer progression. J Cell Biochem 99: 392-401, 2006.

99. Mahadevan D, Sutton GR, Arteta-Bulos R, Bowden CJ, Miller PJ, Swart RE, Walker MS, Haluska P, Munster PN, Marshall J, et al Phase 1b study of safety, tolerability and efficacy of R1507, a monoclonal antibody to IGF-1R in combination with multiple standard oncology regimens in patients with advanced solid malignancies. Cancer Chemother Pharmacol 73: 467-473, 2014

100. Miettinen M, Fetsch JF, Sobin LH and Lasota J: Gastrointestinal stromal tumors in patients with neurofibromatosis 1: A clinicopathologic and molecular genetic study of 45 cases. Am J Surg Pathol 30: 90-96, 2006.

101. Ferner RE: Neurofibromatosis 1 and neurofibromatosis 2: A twenty first century perspective. Lancet Neurol 6: 340-351, 2007

102. Maertens O, Prenen H, Debiec-Rychter M, Wozniak A Sciot R, Pauwels P, De Wever I, Vermeesch JR, de Raedt T, De Paepe A, et al: Molecular pathogenesis of multiple gastrointestinal stromal tumors in NF1 patients. Hum Mol Genet 15 1015-1023, 2006

103. Andersson J, Sihto H, Meis-Kindblom JM, Joensuu H, Nupponen N and Kindblom LG: NF1-associated gastrointestinal stromal tumors have unique clinical, phenotypic, and genotypic characteristics. Am J Surg Pathol 29: 1170-1176, 2005.

104. Mussi C, Schildhaus HU, Gronchi A, Wardelmann E and Hohenberger P: Therapeutic consequences from molecular biology for gastrointestinal stromal tumor patients affected by neurofibromatosis type 1 . Clin Cancer Res 14: 4550-4555, 2008 .

105. Kalender M, Sevinc A, Tutar E, Sirikci A and Camci C: Effect of sunitinib on metastatic gastrointestinal stromal tumor in patients with neurofibromatosis type 1: A case report. World J Gastroenterol 13: 2629-2632, 2007.

106. Cui Y and Guadagno TM: B-Raf (V600E) signaling deregulates the mitotic spindle checkpoint through stabilizing Mps1 levels in melanoma cells. Oncogene 27: 3122-3133, 2008.

107. Matos P, Oliveira C, Velho S, Gonçalves V, da Costa LT, Moyer MP, Seruca R and Jordan P: B-Raf(V600E) cooperates with alternative spliced Raclb to sustain colorectal cancer cell survival. Gastroenterology 135: 899-906, 2008

108. Davies H, Bignell GR, Cox C, Stephens P, Edkins S, Clegg S, Teague J, Woffendin H, Garnett MJ, Bottomley W, et al: Mutations of the BRAF gene in human cancer. Nature 417: 949-954, 2002.

109. Huss S,PasternackH,Ihle MA,Merkelbach-Bruse S,Heitkötter B, Hartmann W, Trautmann M, Gevensleben H, Büttner R, Schildhaus HU and Wardelmann E: Clinicopathological and molecular features of a large cohort of gastrointestinal stromal tumors (GISTs) and review of the literature: BRAF mutations in KIT/PDGFRA wild-type GISTs are rare events. Hum Pathol 62 206-214, 2017.

110. Hostein I, Faur N, Primois C, Boury F, Denard J, Emile JF, Bringuier PP, Scoazec JY and Coindre JM: BRAF mutation status in gastrointestinal stromal tumors. Am J Clin Pathol 133: 141-148, 2010.

111. Rossi S, Gasparotto D, Miceli R, Toffolatti L, Gallina G, Scaramel E, Marzotto A, Boscato E, Messerini L, Bearzi I, et al: KIT, PDGFRA, and BRAF mutational spectrum impacts on the natural history of imatinib-naive localized GIST: A population-based study. Am J Surg Pathol 39: 922-930, 2015.

112. Simanshu DK, Nissley DV and McCormick F: RAS Proteins and their regulators in human disease. Cell 170: 17-33, 2017.

113. Miranda C, Nucifora M, Molinari F, Conca E, Anania MC Bordoni A, Saletti P, Mazzucchelli L, Pilotti S, Pierotti MA, et al: KRAS and BRAF mutations predict primary resistance to imatinib in gastrointestinal stromal tumors. Clin Cancer Res 18 1769-1776, 2012.

114. Pantaleo MA, Nannini M, Corless CL and Heinrich MC: Quadruple wild-type (WT) GIST: Defining the subset of GIST that lacks abnormalities of KIT, PDGFRA, SDH, or RAS signaling pathways. Cancer Med 4: 101-103, 2015.

115. Nannini M, Astolfi A, Urbini M, Indio V, Santini D, Heinrich MC, Corless CL, Ceccarelli C, Saponara M, Mandrioli A, et al: Integrated genomic study of quadruple-WT GIST (KIT/PDGFRA/SDH/RAS pathway wild-type GIST). BMC Cancer 14: 685, 2014
116. Brenca M, Rossi S, Polano M, Gasparotto D, Zanatta L, Racanelli D, Valori L, Lamon S, Dei Tos AP and Maestro R: Transcriptome sequencing identifies ETV6-NTRK3 as a gene fusion involved in GIST. J Pathol 238: 543-549, 2016.

117. Shi Y, Gao X, Hu Q, Li X, Xu J, Lu S, Liu Y, Xu C, Jiang D, Lin J, et al: PIK3C2A is a gene-specific target of microRNA-518a-5p in imatinib mesylate-resistant gastrointestinal stromal tumor. Lab Invest 96: 652-660, 2016.

118. Belinsky MG, Rink L, Cai KQ, Capuzzi SJ, Hoang Y, Chien J, Godwin AK and von Mehren M: Somatic loss of function mutations in neurofibromin 1 and MYC associated factor X genes identified by exome-wide sequencing in a wild-type GIST case. BMC Cancer 15: 887, 2015.

119. Pantaleo MA, Urbini M, Indio V, Ravegnini G, Nannini M, De Luca M, Tarantino G, Angelini S, Gronchi A, Vincenzi B, et al: Genome-wide analysis identifies MEN1 and MAX mutations and a neuroendocrine-like molecular heterogeneity in quadruple WT GIST. Mol Cancer Res 15: 553-562, 2017.

120. Henze J, Mühlenberg T, Simon S, Grabellus F, Rubin B, Taeger G, Schuler M, Treckmann J, Debiec-Rychter M, Taguchi T, et al: p53 modulation as a therapeutic strategy in gastrointestinal stromal tumors. PLoS One 7: e37776, 2012.

121. Stewart CM and Tsui DWY: Circulating cell-free DNA for non-invasive cancer management. Cancer Genet 228-229: $169-179,2018$

122. Wan JCM, Massie C, Garcia-Corbacho J, Mouliere F, Brenton JD, Caldas C, Pacey S, Baird R and Rosenfeld N: Liquid biopsies come of age: Towards implementation of circulating tumour DNA. Nat Rev Cancer 17: 223-238, 2017.

123. Kidess E and Jeffrey SS: Circulating tumor cells versus tumor-derived cell-free DNA: Rivals or partners in cancer care in the era of single-cell analysis? Genome Med 5: 70, 2013

124. Fiala C and Diamandis EP: Utility of circulating tumor DNA in cancer diagnostics with emphasis on early detection. BMC Med 16: 166, 2018.

125. Elazezy M and Joosse SA: Techniques of using circulating tumor DNA as a liquid biopsy component in cancer management. Comput Struct Biotechnol J 16: 370-378, 2018.

126. Maier J, Lange T, Kerle I, Specht K, Bruegel M, Wickenhauser C, Jost P, Niederwieser D, Peschel C, Duyster J and von Bubnoff N: Detection of mutant free circulating tumor DNA in the plasma of patients with gastrointestinal stromal tumor harboring activating mutations of CKIT or PDGFRA. Clin Cancer Res 19: 4854-4867, 2013

127. Namløs HM, Boye K, Mishkin SJ, Barøy T, Lorenz S, Bjerkehagen B, Stratford EW, Munthe E, Kudlow BA, Myklebost $O$ and Meza-Zepeda LA: Noninvasive detection of ctDNA reveals intratumor heterogeneity and is associated with tumor burden in gastrointestinal stromal tumor. Mol Cancer Ther 17: 2473-2480, 2018.

128. Jilg S, Rassner M, Maier J, Waldeck S, Kehl V, Follo M, Philipp U, Sauter A, Specht K, Mitschke J, et al: Circulating cKIT and PDGFRA DNA indicates disease activity in gastrointestinal stromal tumor (GIST). Int J Cancer 145: 2292-2303, 2019.

129. Lujambio A and Lowe SW: The microcosmos of cancer. Nature 482: 347-355, 2012.

130. Steponaitiene R, Kupcinskas J, Langner C, Balaguer F, Venclauskas L, Pauzas H, Tamelis A, Skieceviciene J, Kupcinskas L, Malfertheiner P and Link A: Epigenetic silencing of miR-137 is a frequent event in gastric carcinogenesis. Mol Carcinog 55: 376-386, 2016

131. Balaguer F, Link A, Lozano JJ, Cuatrecasas M, Nagasaka T, Boland CR and Goel A: Epigenetic silencing of miR-137 is an early event in colorectal carcinogenesis. Cancer Res 70: 6609-6618, 2010.

132. Rizzato C, Campa D, Talar-Wojnarowska R, Halloran C, Kupcinskas J, Butturini G, Mohelníková-Duchoňová B, Sperti C, Tjaden C, Ghaneh P, et al: Association of genetic polymorphisms with survival of pancreatic ductal adenocarcinoma patients. Carcinogenesis 37: 957-964, 2016

133. Catanzaro G, Sabato C, Russo M, Rosa A, Abballe L, Besharat ZM, Po A, Miele E, Bellavia D, Chiacchiarini M, et al: Loss of miR-107, miR-181c and miR-29a-3p promote activation of Notch2 signaling in pediatric high-grade gliomas (pHGGs). Int J Mol Sci 18: E2742, 2017.

134. Ihle MA, Trautmann M, Kuenstlinger H, Huss S, Heydt C, Fassunke J, Wardelmann E, Bauer S, Schildhaus HU, Buettner R and Merkelbach-Bruse S: miRNA-221 and miRNA-222 induce apoptosis via the KIT/AKT signalling pathway in gastrointestinal stromal tumours. Mol Oncol 9: 1421-1433, 2015. 
135. Gits CM, van Kuijk PF, Jonkers MB, Boersma AW, van Ijcken WF, Wozniak A, Sciot R, Rutkowski P, Schöffski P, Taguchi T, et al: MiR-17-92 and miR-221/222 cluster members target KIT and ETV1 in human gastrointestinal stromal tumours. Br J Cancer 109: 1625-1635, 2013.

136. Cao CL, Niu HJ, Kang SP, Cong CL and Kang SR: miRNA-21 sensitizes gastrointestinal stromal tumors (GISTs) cells to imatinib via targeting B-cell lymphoma 2 (Bcl-2). Eur Rev Med Pharmacol Sci 20: 3574-3581, 2016.

137. Yamamoto H, Kohashi K, Fujita A and Oda Y: Fascin-1 overexpression and miR-133b downregulation in the progression of gastrointestinal stromal tumor. Mod Pathol 26: 563-571, 2013.

138. Liu S, Cui J, Liao G, Zhang Y, Ye K, Lu T, Qi J and Wan G: MiR-137 regulates epithelial-mesenchymal transition in gastrointestinal stromal tumor. Tumour Biol 35: 9131-9138, 2014

139. Lu HJ, Yan J, Jin PY, Zheng GH, Qin SM, Wu DM, Lu J and Zheng YL: MicroRNA-152 inhibits tumor cell growth while inducing apoptosis via the transcriptional repression of cathepsin L in gastrointestinal stromal tumor. Cancer Biomark 21: 711-722, 2018

140. Fan R, Zhong J, Zheng S, Wang Z, Xu Y, Li S, Zhou J and Yuan F: MicroRNA-218 inhibits gastrointestinal stromal tumor cell and invasion by targeting KIT. Tumour Biol 35: 4209-4217, 2014

141. Yun S, Kim WK, Kwon Y, Jang M, Bauer S and Kim H: Survivin is a novel transcription regulator of KIT and is downregulated by miRNA-494 in gastrointestinal stromal tumors. Int J Cancer 142: 2080-2093, 2018.

142. Huang WK, Akçakaya P, Gangaev A, Lee L, Zeljic K, Hajeri P, Berglund E, Ghaderi M, Àhlén J, Bränström R, et al: miR-125a-5p regulation increases phosphorylation of FAK that contributes to imatinib resistance in gastrointestinal stromal tumors. Exp Cell Res 371: 287-296, 2018.

143. Niinuma T, Suzuki H, Nojima M, Nosho K, Yamamoto H, Takamaru H, Yamamoto E, Maruyama R, Nobuoka T, Miyazaki Y, et al: Upregulation of miR-196a and HOTAIR drive malignant character in gastrointestinal stromal tumors. Cancer Res 72: 1126-1136, 2012.
144. Akçakaya P, Caramuta S, Åhlen J, Ghaderi M, Berglund E, Östman A, Bränström R, Larsson C and Lui WO: microRNA expression signatures of gastrointestinal stromal tumours: Associations with imatinib resistance and patient outcome. Br J Cancer 111: 2091-2102, 2014.

145. Juzėnas S, Saltenienè V, Kupcinskas J, Link A, Kiudelis G, Jonaitis L, Jarmalaite S, Kupcinskas L, Malfertheiner P and Skieceviciene J: Analysis of deregulated microRNAs and their target genes in gastric cancer. PLoS One 10: e0132327, 2015.

146. ElSharawy A, Röder C, Becker T, Habermann JK, Schreiber S, Rosenstiel $\mathrm{P}$ and Kalthoff $\mathrm{H}$ : Concentration of circulating miRNA-containing particles in serum enhances miRNA detection and reflects CRC tissue-related deregulations. Oncotarget 7: 75353-75365, 2016.

147. Alemar B, Izetti P, Gregório C, Macedo GS, Castro MA Osvaldt AB, Matte U and Ashton-Prolla P: miRNA-21 and miRNA-34a Are potential minimally invasive biomarkers for the diagnosis of pancreatic ductal adenocarcinoma. Pancreas 45: 84-92, 2016

148. Kou Y, Yang R and Wang Q: Serum miR-518e-5p is a potential biomarker for secondary imatinib-resistant gastrointestinal stromal tumor. J Biosci 43: 1015-1023, 2018.

149. Schmitt AM and Chang HY: Long noncoding RNAs in cancer pathways. Cancer Cell 29: 452-463, 2016.

150. Bure I, Geer S, Knopf J, Roas M, Henze S, Ströbel P, Agaimy A, Wiemann S, Hoheisel JD, Hartmann A, et al: Long noncoding RNA HOTAIR is upregulated in an aggressive subgroup of gastrointestinal stromal tumors (GIST) and mediates the establishment of gene-specific DNA methylation patterns. Genes Chromosomes Cancer 57: 584-597, 2018.

151. Yan J, Chen D, Chen X, Sun X, Dong Q, Hu C, Zhou F and Chen W: Downregulation of lncRNA CCDC26 contributes to imatinib resistance in human gastrointestinal stromal tumors through IGF-1R upregulation. Braz J Med Biol Res 52: e8399, 2019 . 